\author{
関西地域の住宅における熱的快適性に関する実態調査 \\ 一夏期の中立温度と許容範囲一 \\ A FIELD STUDY OF THERMAL ENVIRONMENT AND THERMAL COMFORT \\ IN KANSAI REGION, JAPAN \\ - Neutral temperature and acceptable range in summer- \\ $\cdot$ \\ 中谷岳史*1, 松原斎樹*2, 藏澄 美仁*3 \\ Takashi NAKAYA, Naoki MATSUBARA and Yoshihito KURAZUMI
}

This report presents the findings of a field study of thermal comfort and thermal environment in 30 detached houses in Hyogo, 30 apartment houses in Osaka,Japan. A total of 70 subjects provided 459 sets of data for summer,each accompanied by indoor climatic measurements. The sample of subjects consisted mostly of housewife.The average clothing insulation levels were $0.28 \mathrm{clo}$. The average metabolic rate was $1.3 \mathrm{met}$.Thermal neutrality, according to responses on the ASHRAE seven-point sensation scale, occurred at $27.6^{\circ} \mathrm{C}$. The Operative temperature corresponding to the accepted thermal environment by $80 \%$ of the occupants is under $28.4^{\circ} \mathrm{C}$.

Keywords: Field study, Thermal comfort, House, Summer, Neutral temperature, Acceptable Range

実態調查, 熱的快適性, 住宅, 夏期, 中立温度, 許容範囲

1.はじめに

住宅の快適な温熱環境をデザインするためには、居住者が快適と 感じる温熱環境の範囲を把握する必要がある。許容範囲や中立温度 は、住宅の空気調和設備の設定温度や制御範囲を定める際に必要不 可欠である。許容範囲に関する研究は、被験者を用いた実験室実験 が長年、数多く行われてきた1) 2)。現在は室内温熱環境基淮として ASHRAE Standard55-200433などにまとめられている。

しかし実際の環境では実験室実験と異なり、居住者は主体的に環 境に働きかけて温熱環境を調整することができる。これは環境調節 行為と呼ばれ、温熱環境の形成に強く影響する4)。過去のオフィスや 学校などを対象とした実態調查では、実験室実験と比べて快適範囲 が広いことが報告されている5 )。環境調節行為は、行動の自由度に強 く制約される。一般にオフィスや学校空間では、空の開閉、扇風機 による気流速の増加、着衣量の増減が自由にできない。一方、住宅 は行動の自由度が高く、実験室、オフィスよりも幅広い許容範囲を 有する可能性がある ${ }^{6\rangle}$ 。

中立温度、許容範囲に関する既往研究は国内外のオフィス 5)7)-12)で 数多く行われている。しかし日本の住宅を対象とした害態調查は少 なく13)-15)、代謝量や着衣量などの要因は考慮されていない。また許 容範囲を求めた研究はない。日本の住宅は、欧米やオフィスとは異 なる生活様式を持つため、他の地域の既往研究結果とは異なること が予想される。そのため日本の住宅を対象とした中立温度や許容範
囲を明らかにしておく必要がある。

そこで本研究では関西地域の住宅を対象とした赛態調查をおこな い、温熱環境および居住者の環境調節行為を把握するとともに、日 本の住宅でまだ求められていない、中立温度と許容範囲を明らかに することを目的とする。

\section{2. 調查概要}

調查対象地域は兵庫県宝塚市の戸建住宅及び大阪府高梘市の集合 住宅である。両地域とも関西の温暖な地域にあり、調査期閒中の平 均外気温は最需の気象台デー夕によれば、兵庫で $28.2{ }^{\circ} \mathrm{C}$, 大阪府で 28. $4^{\circ} \mathrm{C}$ であった(図1)。

住戸種類は、戸建住宅（兵庫県宝塚市）及び集合住宅（大阪府高䙺 市)である。調查住戸数は戸建住宅 31 戸, 集合住宅 31 戸である。戸建 住宅の居住年数は2 30年 (平均 11 年) である。な晾調查対象住戸の中 に次世代省エネルギー基準をみたす住戸は含まれていない。集合住 宅は居住年数が $1 \sim 24$ 年(平均 9 年)である。住戸階数は 5 階建てまでで あり、高層集合住宅は含まれていない。夏期の涼の取り方として は、通風, 扇風機, 空調 (エアーコンデ仗ン)を単独, もしくは組み合わせて いた。調查人数は70人 (男性6人, 女性 64 人) で、平均年齢は 46 歳 (24〜 73 歳)であった。

娚查内容は、(1)室内の温熱環境測定(2)生活時間調查(3)温熱環境に 対する主観申告、の3 種類であった。調查訪問時に(1)の測定機器を設
*1 大和ハウス工業(侏) 修士(学術)

*2 京都府立大学人間環境学部環境デザイン学科 教授・上博

*3 京都府立大学人間環境学部環境デザイン学科 助教授・工博
Daiwa House Industry Co., Ltd., Ph. M.

Prof., Dept. of Environmental Design, Kyoto Pref. Univ., Dr. Eng.

Assoc. Prof., Dept. of Environmental Design, Kyoto Pref. Univ., Dr. Eng. 
外気温度 (平均, 最小, 最大)

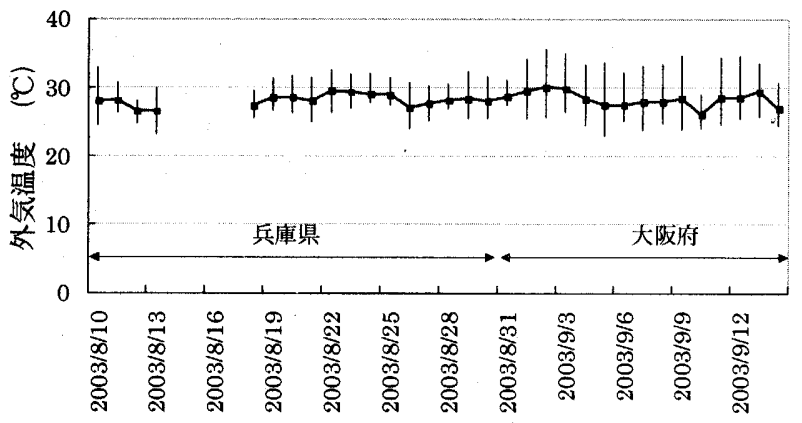

図 1 実測期間中の外気温度

置するとともに、居住者に調査内容の説明をした。二日間の調查期 閒中は、居住者に(2)(3)の記入を依頼した。

調查期間は 2003 年8月11日〜9月10日である。8月 14 日〜17日のお 盆期間は調查を休止した。調查期間は各住戸 4 日間である。各住戸 には事前に連絡をして調査の承諾を得てから訪問を行った。調查初 日は、再度調查協力の確認を行い、趣旨の説明、室内人の調查器具 設置の承諾, 調查器具の説明, 調査器具の設置, 主観申告- 生活時間 調査用紙の説明を行い、被験者から質問がないか最後に尋叔た。ま た測定期間中は普段通りに生活するように教示を与えた。2 日目上 3 日目に、被験者は主観申告及び生活時間調查用紙に記入を行い、 測定器具で環境データを自動記録した。4 日目に用紙及び測定器具 の回収を行い、用紙の記入に不備があれぱ口頭で補足した。調査終 了後に、相当分の謝礼全被験者に手渡した。室内の温熱環境の 測定項目は、環境側 4 条件 ( 空気温度 $\mathrm{a} \cdot$ ・゙ローブ温度 $\mathrm{g} \cdot$ ・湿度 $\mathrm{RH} \cdot$ 気流速V ) と人体側 2 条件 (代謝量M・着衣量 I c l) である。環境 側条件の測定は、グローブ温度計 $(\phi=150 \mathrm{~mm})$ ，携帯型データロガー (エスペック社製 RS-11, RT-11), 熱線風速計 (KANOMAX社製, Model 6021）を用いた。測定点は、気温：床上0.1 $\mathrm{m}, 0.7 \mathrm{~m}, 1.1 \mathrm{~m}$ 、湿度, 気流 速: 床上 $1.1 \mathrm{~m}$ 、黒球温度計：床上 $0.7 \mathrm{~m}$ とした。測定間隔は5 分であ る。温度データは回収後に、三項移動平均によるノイズ除去をおこ なった。人体側条件は被験者が所定の用紙に記入した。着衣量は、 日中・夜間・就寝時の着衣を用紙に記入させた。着衣量の推定は、 日本人の着衣生活実態を反映していると考えられる花田ら18)の方法 を用いた。代謝量は主観申告回答時に記入させた。代謝量は主観申 告の際に5段階の作業強度 $(0.8 \sim 2.0 \mathrm{met})$ を記入させることで推定 した $\left.{ }^{3}\right) 。$ 主観申告は、居住者自身に記入させた。測定した測定項目 をもとに、環境指標である作用温度, 新有効温度, 標淮新有効温度 (以後、To, $\mathrm{ET}^{*}, \mathrm{SET}^{*}$ ) 求就。

生活時間調查注〉に用いた調查用紙は、横軸々時間軸, 縦軸に行為 軸を10分単位で記入させた。調查対象となる居住者行動は、生活 必需時間「睡眠，食事，身の回りの用事」に加え、空調，空開閉，扇 風機の使用時間である。生活時間調查の結果はデー夕を「通風時」

と「空調時」に分類するために用いた。

主観申告は、温冷感，熱的許容度，熱的快適感を用いた。申告を するにあたり、温冷感，熱的快適感は回答者自身の身体の感じ力 を、温熱的許容度は室内の熱環境を受け入れられるかを評価寸るよ

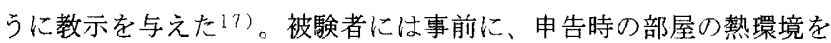

表 1 環境要因の測定結果

\begin{tabular}{|c|c|c|c|c|}
\hline Hets & 平均 & 標準偏差 & 最小値 & 最大値 \\
\hline & 28.9 & 1.8 & 23.9 & 33.1 \\
\hline 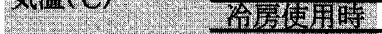 & 28.0 & 1.6 & 24.2 & 32.0 \\
\hline 101 & 29.5 & 1.7 & 23.9 & 33.1 \\
\hline & 28.9 & 1.9 & 23.8 & 34.9 \\
\hline 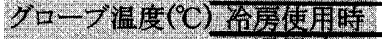 & 28.1 & 1.6 & 26.8 & 30.4 \\
\hline 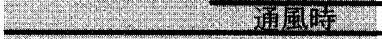 & 29.4 & 1.9 & 23.8 & 34.9 \\
\hline & 65.9 & 11.4 & 37.5 & 91.6 \\
\hline 相社湿度 $(\%)$ & 56.7 & 9.4 & 37.5 & 87.0 \\
\hline 通等時 & 70.6 & 8.6 & 49.9 & 91.6 \\
\hline (1) & 16.6 & 3.2 & 8.2 & 22.6 \\
\hline 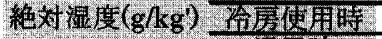 & 13.5 & 2.6 & 8.2 & 21.3 \\
\hline 通俨清古 & 18.3 & 1.8 & 12.1 & 22.6 \\
\hline & 28.4 & 1.9 & 23.2 & 33.5 \\
\hline X原 & 27.7 & 1.6 & 23.2 & 33.0 \\
\hline - & 28.9 & 1.9 & 23.6 & 33.5 \\
\hline X流速 $(\mathrm{m} / \mathrm{s})$ & 0.11 & - & 0.01 & 0.40 \\
\hline 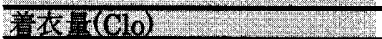 & 0.28 & 0.06 & 0.15 & 0.46 \\
\hline 代谓 & 1.34 & 0.39 & 0.90 & 2.00 \\
\hline
\end{tabular}

評価するよう依頼した。主観申告は午前 8 時から午後 12 時まで 2 時間 毎の指定申告、及び時間指定なしの自由申告上した。また「空調開 始直後」「帰宅直後」「入室直後」「入浴直後」などの状況にあて はまるかを、申告の際に記入させた。空調の開始による室温の急激 な低下状態や、帰宅直後や入浴後の体温が上昇した状態の申告は、

「室滞在者の許容範囲の算出」に適さないと判断して分析から除外 した。その結果、本報告で分析に用いる主観申告数は459である。

温泠感申告 (以後、TSV) は、ASHRAEの7段階の温泠感尺度の日本語 訳を用いた。「寒い(1)」「暑い（7）」を両極に配置して、中央に 「どちらでもない(4)」を配置した。熱的許容度は、6段階の両極尺 度であり、環境に対する感じ方を門极る申告である18)。「とても許容 できない(1)」「とても許容できる（6）」を両極に配置した。熱的快

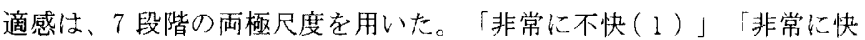
適 (7)」を両極上して、中央に「中立(4)」を配置した。

\section{3. 測定結果}

\section{1 生活時間調查}

全申告の環境調節行為（冷房使用，通風，扇風機使用）の割合を、生 活時間調查の結果から示す。環境調節行為を行っていない申告怡全 体の3.5\%(n=14)，冷房使用は36.0\% $(n=171)$ ，そして通風怯60.5\% （n=284）であった。冷房の使用頻度は、通風の半分程度であり、夏期 の住宅に技いては、通風の割合が高いことが示された。扇風機老使 用しているのは、全申告の $40.6 \%(\mathrm{n}=192)$ であった。各行為別にみる 上、通風時に扇風機併用してるのは $44.3 \%(n=126)$ 、冷房使用時に 扇風機を併用しているのは36.2\%(n=62)であった。扇風機法、冷房や 通風と組み合わせて日常的に用いられていた。

\section{2 物理環境}

測定期間中の室内の物理環境の測定結果を示す（表 1 ）。また図 $2 に$ 気温と相対湿度の累積確率プロットを示す。測定データの70\%が気温 $28^{\circ} \mathrm{C}$ 超え、データの $40 \%$ が相対湿度 $70 \%$ を回っていた。日本の夏 期の住宅温熱環境は、ビル衛生管理法 19$)$ の上限基準 (気温 $28{ }^{\circ} \mathrm{C}$ 以下, 湿度7 0 \% 以下）から外れた、高温多湿な環境である。また、申告時の 居住者は軽度の作業強度をおこない、薄着ですごしていた。 

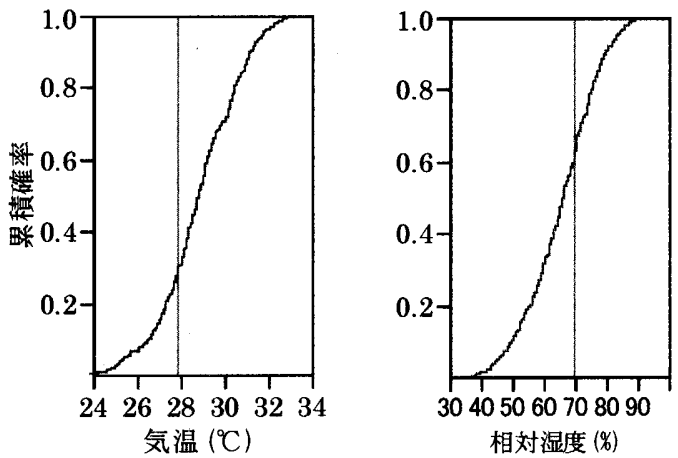

図 2 気温と湿度の累積確率プロット

表 2 温熱環境指標の結果

\begin{tabular}{|c|c|c|c|c|}
\hline & 平均 & 標準偏差 & 最小值 & 最大值 \\
\hline PMV & 5.1 & 0.9 & 2.2 & 6.8 \\
\hline PPD $(\%)$ & 39.3 & 28.5 & 5.0 & 98.1 \\
\hline SDT (C) & 27.3 & 2.5 & 21.0 & 32.5 \\
\hline $\operatorname{EP}(\mathrm{C})$ & 29.9 & 2.2 & 24.1 & 34.4 \\
\hline $\ln _{n}(\mathrm{C})$ & 28.9 & 1.8 & 23.9 & 33.8 \\
\hline
\end{tabular}

表 3 主観申告結果

\begin{tabular}{|c|c|c|c|c|c|}
\hline & 挨 & 平均 & 標準偏差 & $\begin{array}{l}\text { 最小值 } \\
\end{array}$ & 最大値 \\
\hline & & 4.6 & 1.8 & 1.0 & 7.0 \\
\hline & 经房使闻時 & 3.4 & 1.4 & 1.0 & 7.0 \\
\hline & 诵栭助 & 5.4 & 1.5 & 1.0 & 7.0 \\
\hline & & 4.4 & 1.1 & 1.0 & 6.0 \\
\hline 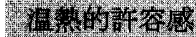 & 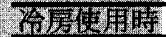 & 4.8 & 1.0 & 1.0 & 6.0 \\
\hline & 驱通風時 & 4.1 & 1.0 & 1.0 & 6.0 \\
\hline & & 4.5 & 1.5 & 1.0 & 7.0 \\
\hline 楊慗新 & 需盾便用晴 & 5.4 & 1.4 & 1.0 & 7.0 \\
\hline & 通風時 & 3.9 & 1.3 & 1.0 & 7.0 \\
\hline
\end{tabular}

気温 (FL. 1. $1 \mathrm{~m}$ ) は23.9 33. $1^{\circ} \mathrm{C}$ の範囲で変動し、平均 $28.9^{\circ} \mathrm{C}$ であっ た。行為の種別にみる上、冷房使用時の平均は2 $8.0{ }^{\circ} \mathrm{C}$ であるに対 して、通風時の平均は $29.5^{\circ} \mathrm{C}$ であり、冷房使用時よりむ $1.5^{\circ} \mathrm{C}$ 高い。 また上下温度差(FL. $1.1 \mathrm{~m}-0.1 \mathrm{~m}$ )の平均は $0.6^{\circ} \mathrm{C}$ であった。上下温度差 は空調時で $0.4^{\circ} \mathrm{C}$, 通風時で $0.7^{\circ} \mathrm{C}$ であり、両者に大きな差はみられな かった。また冷房使用時の最大上下温度差は $1.8^{\circ} \mathrm{C}$ であり、I S 07730 の基準 $\left(3{ }^{\circ} \mathrm{C}\right)$ 内であった。

室内の相対湿度は、37.5 91.6\%の範囲で変動し、平均は65.9\%で あった。また絶対湿度は8.5〜23.0 g/ $/ \mathrm{kg}^{\prime}$ の範囲で、平均は $16.9 \mathrm{~g} /$ kg'であった。ASHRAE Standard55-2004が定める基準 $\left(12.0 \mathrm{~g} / \mathrm{kg}^{\prime}\right)$ を 超えていた。さらに通風時に限定すると、絶対湿度の平均は1 $8.8 \mathrm{~g} /$ kg'であり、ASHRAEの基準を大きく逸脱している。これらは通風時に 外気湿度から強く影響された結果と考えられる。グローブ温度は、

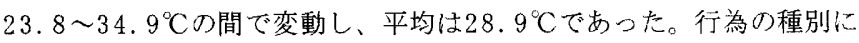
みると、椧房使用時は $28.2{ }^{\circ} \mathrm{C}$ であるのに対して、通風時は $29.4{ }^{\circ} \mathrm{C}$ と 約 $1{ }^{\circ}$ C高い値であった。気流速は、測定器の制約により全住戸の測定 はできなかった。一部ではあるが、6 件の測定データの平均值を解析 に用いることとする。測定結果は、平均 $0.1 \mathrm{~lm} / \mathrm{s}$, 最大 $0.29 \mathrm{~m} / \mathrm{s}$, 最小 $0.01 \mathrm{~m} / \mathrm{s}$ で女った。次に人体側条件、代謝量与着衣量の測定結果を示 す。代謝量は平均 $1.3 \mathrm{met}$ であった。こ礼は室内の軽い軽作業に相当

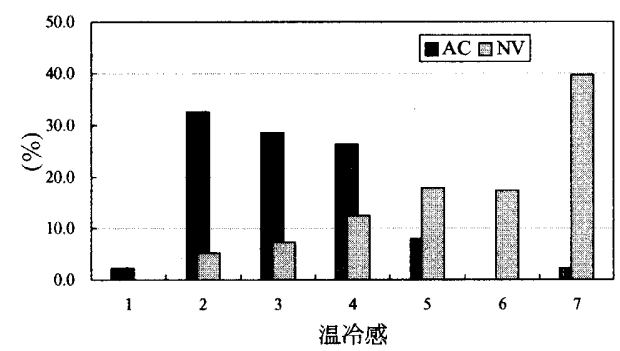

図 3 温冷感申告の結果

表 4 温冷感と各種温熱指標の相関

\begin{tabular}{|c|c|}
\hline & 温冷感 \\
\hline To & $0.61^{* * *}$ \\
\hline $\mathrm{ET}^{*}$ & $0.66^{* * *}$ \\
\hline SET* & $0.62^{* \star \star *}$ \\
\hline PMV & $0.57^{* \star \star}$ \\
\hline $\mathrm{Ta}$ & $0.63^{\star \star \star}$ \\
\hline $\mathrm{Tg}$ & $0.59^{* \star *}$ \\
\hline Tout & $0.36^{\star \star *}$ \\
\hline
\end{tabular}

寸る作業強度である。また着衣量は $0.15 \sim 0.46$ (平均0.28) cloであっ 太。代表的な着衣例は、薄手の半そでシャツ，丈の短いズボン，下着 といった組み合わせであった。

\section{3 各種温熱指標}

各種温熱指標の測定期間中の算定結果示吉（表2）。実測結果に 法、平均値 (Mean)、標準偏差 (S. D. )、最小值 (Min.) 、最大値(Max.)

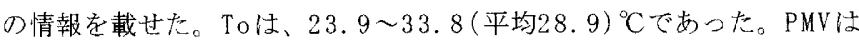
2. 2 6. 8 (平均5.1)、PPDは5.0 98.1 (平均 39.3 ) \%であった。暑熱側 に申告が予想され、不満率もやや高い值となった。SET*は21.0〜32.5 (平均27.3) ${ }^{\circ} \mathrm{C} 、 \mathrm{ET}^{*}$ は2 $24.1 \sim 34.4$ (平均29.9) ${ }^{\circ} \mathrm{C}$ であった。

\section{4 主観申告}

主観申告の結果を示す（表 3)。温冷感の平均は4.6であり、「中立 （4）」〜「やや暖かい（5）」に申告が分布している。 熱的許容度は平 均4.4であり、「やや許容できる $(4) 」 \sim$ 許容できる (5)」に申告の

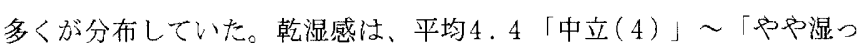
ている(5)」であった。通風時は空調時と比べて1ポイント高く、相 対湿度の影響を強く受けている。相対湿度の許容度は平均 4 。4 であ り、「やや許容できる(4)」〜「許容できる(5)」に申告の大部分が

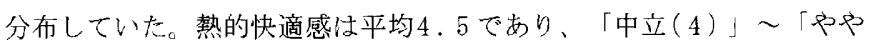
快適(5)」に申告の大部分唯分布していた。

\section{4. 考察}

\section{1 中立温度}

中立温度とは、温冷感尺度「どちらでもない $(T S=4) 」 に$ 相当する 室内温度である。中立温度は、線形回帰分析により求めた。目的変 数は温冷感尺度老用い、説明変数をTo, ET*として、それ卆れ線形回 州分析により求めた。

説明変数の選択は、温冷感申告との相関, 既往研究との比較、の観 
表 5 既往研究との比較 (中立温度, 許容温度)

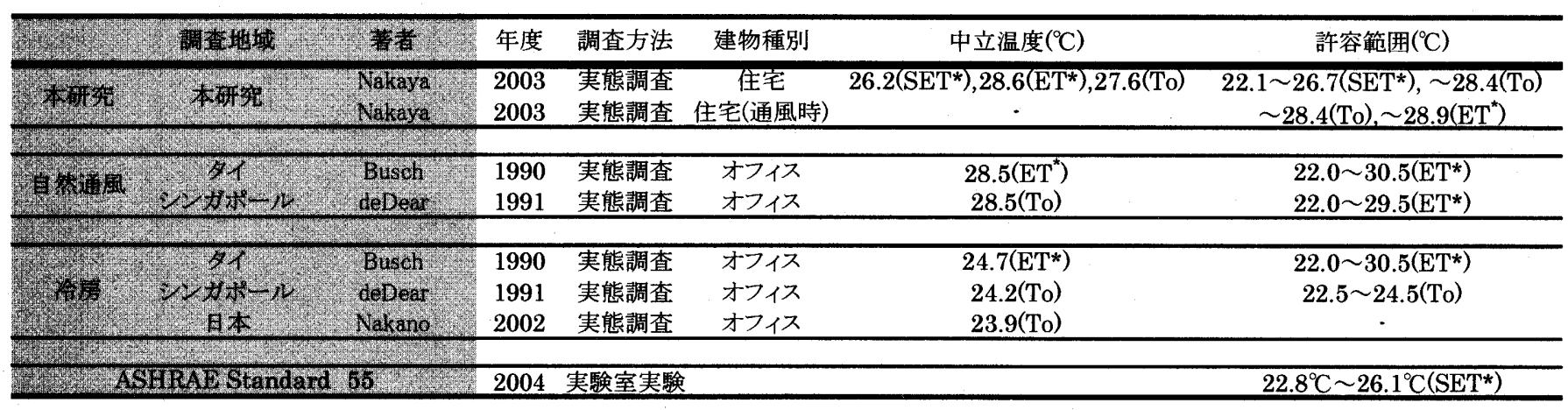

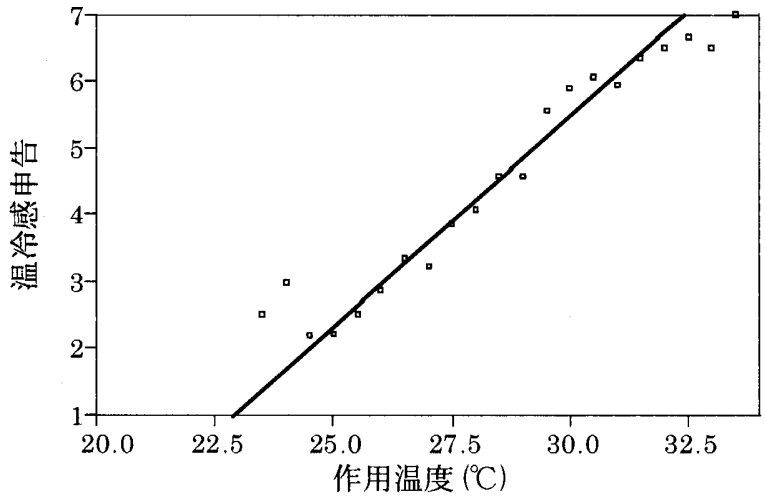

図 4 室内作用温度と平均温冷感申告

点から行う。説明変数は、主観申告を説明寸るための温度であり、 過去の研究に用いられてきたものには、To, ET*, SET*, PMV, Ta, Tg, Tout (外気温度)の7 種類がある。PMVは、予測温椧感指標であるため、中 立温度の検討対象から除外した。温度と温椧感申告（TS）の関係を、 ピアソンの相関倸数で解析することにより調べた（表 4)。各種温度 ( To, E T*, SET* PMV , Ta, T g ) と温冷感の間には、 $(\mathrm{r}=0.57 \sim$ $0.66, \mathrm{p} .<0.0001)$ それぞれ正の相関関係が観察された。しかし外気温 度と温椧感の相関係数给他の温度と比べて相対的に低く $(\mathrm{r}=0.36, \mathrm{p} .<0.0001)$ 、説明変数と寸るには不適当と判断した。初期 の実態調查研究は、説明変数に気温やグローブ温度を用いることが 多かった。しかし近年は、複数の環境要因を組み込んだ環境指標が 主流である。そこで本研究では、回帰分析の説明変数に、 To, ET*, SET*用いる。そして説明変数ごとに単回帰分析を用いて回 帰式を算出し、検討する。

回帰分析を行うために、0. $5^{\circ} \mathrm{C}$ 単位で切り上げたTo, ET ${ }^{*}, \mathrm{SET}^{*}$ に対応 する温冷感申告值の平均僆を目的変数とした。プロットした平均温 椧感のサンプル数に応じた重み付け線形回帰分析を行った（図4)。

$\mathrm{TSV}=0.63 \mathrm{To}^{-}-13.45$

回帰式は統計的に有意なものであり、あてはまりも良い $\left(F=328.9\right.$, prob. $\left.<0.0001, R^{2}=0.95\right)$ 。温冷感申告で「どちらでもない $(T S V=4) 」 に$ 相当する温度を、中立温度とした。ET* SET*についても 同様の分析を施した結果、中立温度は $27.6{ }^{\circ} \mathrm{C}(\mathrm{To}), 28.6{ }^{\circ} \mathrm{C}\left(\mathrm{ET}^{*}\right)$, 26. $2^{\circ} \mathrm{C}$ (SET*) となった。

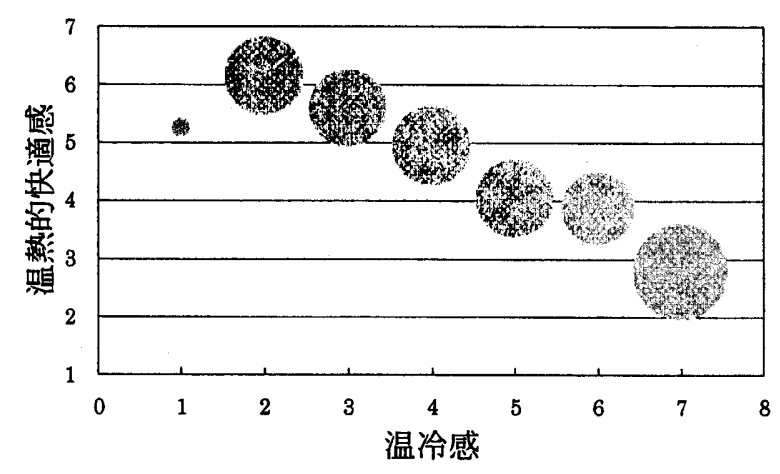

図 5 温冷感申告と快適感申告

次に通風時，冷房使用時の申告を線形回帰で中立温度を予測しよう としたものの、通風時の申告は暑い側, 空調時の申告は涼しい側に大 きく偏っていた。徉って「どちらでもない(TSV=4)」に相当する温度 が外择となる恐れがあるため、分析をおこなわなかった。

次に、本調查の中立温度と、各国の暑熱地域の既往研究を比較し た結果を示す (表5)。暑熱地域の既往研究で空調オフィスと自然通風 オフィスの比較をすることで、空調方式の影響について検討する。

タイのオフィスを対象とした調查20)では、自然通風オフィスで中立 温度 $28.5^{\circ} \mathrm{C}\left(\mathrm{E} T^{*}\right)$ であるのに対して、空調オフィスの中立温度は 24.7 ${ }^{\circ} \mathrm{C}\left(E T^{*}\right)$ であった。またシンガポールのオフィスを対象とした調査 ${ }^{21)}$ では、中立温度は自然通風オフィスで $28.5{ }^{\circ} \mathrm{C}(\mathrm{T} 0)$, 空調オフィスで $24.2{ }^{\circ} \mathrm{C}(\mathrm{T} 0)$ であった。日本では東京の空調オフィスを対象とした調 查 ${ }^{14)}$ が行われており、中立温度が $23.99^{\circ} \mathrm{C}(\mathrm{T} 0)$ であることが報告され ている。

本調査の中立温度は、暑熱地域の自然通風オフィスとほぼ同様の 值を示した。またタイ、シンガポールと同様に、日本においても空調 と自然通風といった空調方式の差により、中立温度で $3 \sim 4{ }^{\circ} \mathrm{C} の$ 差が

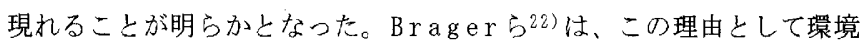
調節行動の影響に加え、室温に対する期待感が影響する可能性を指 摘している。

温泠感と熱的快適感の関倸を図 5 に示す。横軸は温椧感尺度, 縦軸 は熱的快適感尺度である。円の大きさは、申告数を表している。最 も快適感が高いのは、温冷感が「涼しい」とさである。「涼しい」 
表 6 温冷感と温熱的快適感

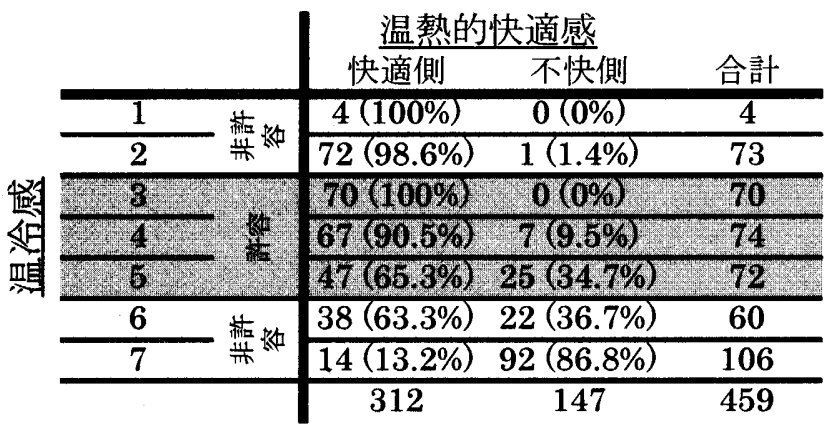

表 7 温熱的許容感と温熱的快適感

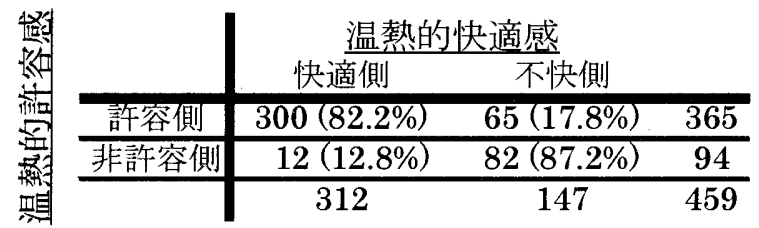

〜「暑い」にかけて、熱的快適感が低下寸る傾向が示された。 McIntyr e ${ }^{23)}$ は温暖気候では「やや涼しい」が好まれることを示した が、本研究の結果は、「やや涼しい」よりもさら汇涼しい側である 「涼しい」の申告時に、熱的快適感がもっとも快適な側にあること を示している。

\section{2 許容範囲}

ASHRAE Standard55-2004では、熱的竍容範囲を「不満足者率が 20\% 以下となるような空間」を実現する温度範囲を定めたもの上定義し ている。本研究では、この定義を用いて、熱的許容率上熱的許容範 囲を算出する。

熱的吘容範囲の算出方法には、間接的竍容( Indirect Acceptable ) と直接的許容 (Direct Acceptable)の2種類の方法がある。間接的竍 容は、7段階の温冷感尺度の中央3 段階(やや涼しい〜やや暖かい)を 許容範囲上寸る方法である。一方、直接的許容は、6 段階の許容感の 許容側（やや〜非常比許容できる）を熱的許容度とする方法である。 両方々も実験室実験，実態調查を問わず広く一般的に用いられてい る。表6 に、間接的許容と熱的快適感のクロス集計を示寸。間接的許 容の定義では寒い側の不快領域である「寒い」「涼しい」の申告時 にも、ほぼ全申告が熱的に快適上回答している。つまり「寒い」

「涼しい」環境を快適であると評価している。すなわち間接的許容 では、「寒い」「涼しい」を適切に評価できないため、本研究の分 析には不適当である。次に表 7 亿、直接的許容と熱的快適感のク口 又集計を示す。熱的許容感で非許容側の場合、8 7 \% 以上が温熱的 快適感では不快側の申告となって扰り、間接的許容上りも、妥当な 結果が得られている。以上より、本研究では熱的許容率及び熱的許 容範囲の算出に直接的許容を用いる。

許容率の算出は、許容側申告が全申告に占める割合を求める。温 熱的許容度尺度を6段階にしているため、申告を非許容側 $(+1 \sim+3)$ 女

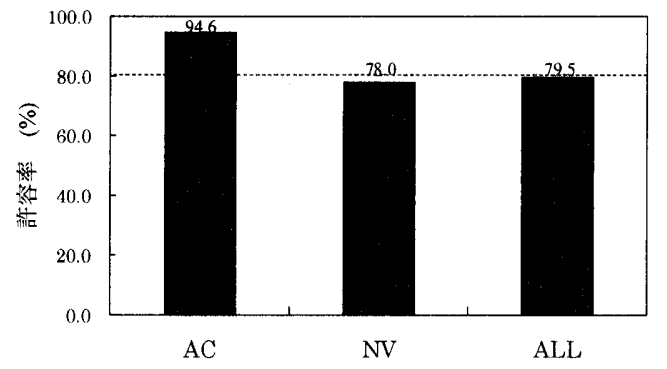

図 6 許容率 (冷房使用時, 通風時, 全申告)

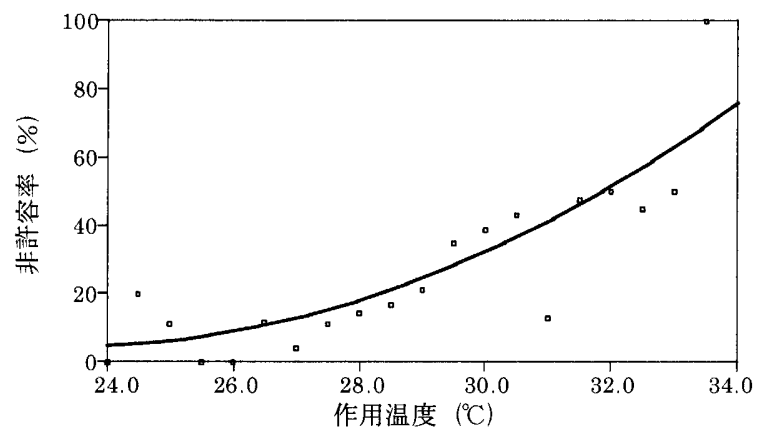

図 7 作用温度と非許容率

許容側 $(+4 \sim+6) の 2$ 種類にまとめた。熱環境を許容側に申告した割合 は、全申告で $80.0 \%$ 、空調時の申告では $94.6 \%$ 、通風時の申告では $78.0 \%$ ある(図6)。多くの居住者は今回調查した環境を許容できる と申告している。既往研究では、八ワイの自然通風の小学校2 4 ) で $86 \%$ ，など、暑熱地域においても $80 \%$ に達している。同様に湿度の許容 率についても検討をおこなった。湿度環境を許容できると申告した 割合は、空調時で $92 \%$, 通風時で7 $8 \%$ であった。温度, 湿度の両方の面 について、居住者は許容できると感じていた。今回、対象とした住 宅の通風時の熱環境は、ASHRAE Standard 55-2004で具体的に示され た熱環境条件からはかなり逸脱していた。それにも関わらず、78\%の 許容率であったという事実は、注目に值すると言えるだろう。日本 で調査することの意義が確認されたとも言える。

熱的許容範囲の算出には、許容度の不快側を分析に用いる。許容 範囲を算出するために、 $0.5^{\circ} \mathrm{C}$ 単位で切り上げたSET*,Toに対応する平 均非許容率を目的変数とした。プロットした平均非許容率のサンプ ル数に応じた2 次の重み付け重回帰分析を行った。そして非許容率が $20 \%$ 以下となる温度範囲を、許容範囲とした（図 7)。横軸は温度, 縦 軸は非許容率である。E T * 㤝計的に有意な回帰式が得られなかった ため、熱的許容範囲の下限を求めることはできなかった。SET*の $80 \%$ 許容範囲は、22. $1^{\circ} \mathrm{C} \sim 26.7^{\circ} \mathrm{C}\left(\mathrm{SET} T^{*}\right)$ であった。またT。の80\%許容範囲 の上限は、 $28.4^{\circ} \mathrm{C}$ あっあた。

同様に通風時の熱的許容範讲の上限温度を検討寸る( 泠房時は許容 側の申告が多いため、非許容範囲算出することができなかった）。 主観申告を生活時間調查をもとに分類を行い、「通風」，「通風之扇 風機の併用」の 2 状態をあわせた申告を、通風状態の申告とする。 SET*を説明変数上したよきは、熱的許容率が $80 \%$ に達しないために熱 的許容範囲を求めることができなかった。そこでT。を説明変数に用 いて分析をおこなった（図 7)。80\%許容範囲の上限は、 $28.4{ }^{\circ} \mathrm{C}$ ( To) , $28.9^{\circ} \mathrm{C}\left(\mathrm{ET}^{*}\right)$ であった。また、 $29.8^{\circ} \mathrm{C}(\mathrm{To})$ で非許容率が $30 \%$ 上なる。 


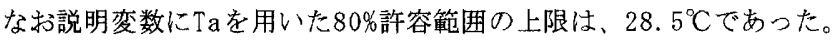

\section{5. 結論}

関西地域の住宅を対象として、室内の熱環境に関する実態調査を 行った。熱環境の測定結果と主観申告の調査結果を、生活時間調査 に基づいて整理・分析した。温冾感申告と熱的許容範囲について検 討した結果を以下にまとめる。

$1 ）$ 測定期間中の室内熱環境は、かなり高温多湿であった。特に通風 時の環境はASHRAEの基準值を大きく逸脱していた。しかし許容率は $80 \%$ でり、通風時でも $78.0 \%$ が室内の温熱環境を許容できるとして いる。従って、居住者の多くは、実測期間中住宅の温熱環境を容認 していたといえる。

2) 今回の調查から求められた中立温度は $27.6^{\circ} \mathrm{C}(\mathrm{To}), 28.6^{\circ} \mathrm{C}\left(\mathrm{ET}^{*}\right)$, $26.2^{\circ} \mathrm{C}\left(\mathrm{SET}^{*}\right)$ であった。これらの数值は、暑熱地域の自然通風オフィ スとほぼ同様の值であるが、東京のオフィスの数值よりは、かなり 高い値である。

3) 今回の調查から求められた熱的許容範囲の上限温度は $28.0^{\circ} \mathrm{C}(\mathrm{T} 0)$ であった。また通風時の熱的許容範囲の上限温度 $28.4{ }^{\circ} \mathrm{C}(\mathrm{T}$ o) であっ た。

今回の調查で得られた中立温度と許容範囲に関する知見は、住宅 における室温の目標値に活用することが考えられる。また夏期に空 調を用いずに、通風で温熱的快適性を保持できる温度範囲の基準に 用いることができる。

\section{謝辞}

調查に協力をいただいた居住者の皆様に感謝いたします。なお，本 研究の一部に, 平成1 $4 \sim 16$ 年度科学研究費基盤研究（ C ）（2） No. 14580123（代表者 松原紊樹）の助成を受忛た。

注）生活時間調查は日記法を中心に行い、面接法で補足をした25)。日 記法とは、被験者に1日の行動を所定の用紙に記入させる方式であ る。この方式の久点は、誤りが生じやすいことや、記入の細かさや 丁寧さに個人差が生じることである。そこで事前に入念な説明をし た上で記入例を添付した。また用紙回収の際には、記入用紙をも上 に面接を行った。特に朝, 夕食前後は複数の生活行動が生起, 終了寸 る為、注意樑く確認した。

\section{参考文献}

1) Gagge, A. P. and Stolwijk, J. A: An effective temperature scale based on a simple model of human physiological regulatory response, ASHRAE Transactions77(1), 247-262, 1971

2) Fanger, P. 0. : Calculation of thermal comfort: introduction of a basic comfort equation, ASHRAE Transaction, 73(2b), 1967

3) ASHRAE: ASHRAE Standard55-2004, Thermal environmental conditions for human occupancy, Atlanta American Society of Heating, Refrigerating, and Air-Conditioning Engineers. Inc, 2004 4) Humphreys. M, Nicol.J: Understanding the adaptive approach to thermal comfort, ASHRAE Transactions104(1B), 991-1004, 1998 5) de Dear. R, Brager. G: Developing an adaptive model of thermal comfort and preference, ASHRAE Transactions 104(1A), 145-167, 1998

6) 中村泰人：才刀仅と住宅の至適温度の差異に関する考察，日本建築学 会学術講演梗概集 D, 903-904, 1995

7) Busch. J.F: Thermal responses to the Thai office environment,
ASHRAE Transactions 96(1), 859-872, 1990

8) de Dear. R, Fountain. M: Field experiments on occupant comfort and office thermal environments in a hot-humid climate, ASHRAE Transactions $100(2), 457-475,1994$

9) Heidari.S, Sharples: A Comparative Analysis of Short-term and Long-term Thermal Comfort Surveys in Iran, Energy and Buildings $34,607-614,2002$

10) Nicol et al. : A survey of thermal comfort in Pakistan-toward new indoor temperature standards-, 0xford Brookes University, 1994

11 ) 成瀬哲生: 温熱環境と温冷感・着衣量に関する現場実態調査一学校 の教室，空気調和·衛生工学 $54(1) ， 1-7,1980$

12 ) 坊垣和明·宮田紀元：室内環境の居住後評価システムその2 才 フィスにおけるPOE調查の結果, 日本建築学会大会学術講演梗概集 D, $119-120,1990$

13) 三浦寿幸・宮尾健一：事務所建築における室内環境実態調査 その5 冷房期の熱環境，日本建築学会大会学術講演梗概集 D， 133-134, 1990

14) Nakano, J. et al. : Differences in perception of indoor environment between Japanese and non-Japanese workers, Energy and Buildings 34, 615-621, 2002

$15)$ 都築和代ほか: 関東地域の住宅における乳幼児の衣住温熱環境調

査, 日本家政学会誌 $52(5), 429-438,2001$

16) 花田嘉代子, 三平和雄, 任藤由美：緎維製品消費科学会誌 24,363 , 1983

17)梅宮典子・中村泰人：温熱環境評価研究における温感申告調查法 の変遷 海外の研究におけるThermal Comfortの申告調查法, 日本建 築学会計画計論文集, 518, 13-20, 1999

18) deDear, R. J. : Field experiments on occupant comfort and office thermal environments in a hot-humid climate, ASHRAE Transactions $100(2), 457-475,1994$

19 ) 建築物に扮ける衛生的環境の確保に関する法律, 昭和 45 年法律第 20 号

20)Busch, J.F. Thermal responses to the THAI office environment, ASHRAE Transaction 96(1), 859-872, 1990

21) deDear, R. J. : Thermal comfort in the humid tropics: Field experiments in air conditioned and naturally ventilated buildings in Singapore, International Journal of Biometeorology 34, 259-265, 1991

22) Brager, G. and de Dear, R. : Thermal adaptation in the build environment: a literature review, Energy and Building 27, 8396, 1998

23) McIntyre, D. A. : Indoor Climate, London, Applied Science Publishers, 1980

24) Kwok, A. : Thermal comfort in tropical classrooms, ASHRAE Transactions 104(1B), 1031-1047, 1998

25) 矢野眞和：生活時間の社会学 社会の時間-個人の時間, 東京大学 出版会, 1995

\section{本研究に関連する発表論文}

1) 中谷岳史ほか(2004)：住宅室内の中立温度に関する実態調査一関西 地域の戸建·集合住宅を対象として一，第28回人閒一生活 環境系シンポ ジウム報告集， 5-8

2) 中谷岳史ほか(2004)：居住室の温熱環境に関する調査研究(その 1) 関西地域の住宅を対象とした中立温度の把握，日本建築学会学術 講演梗概集 D2，113-114

(2005年 4 月 10 日原稿受埋，2005年 8 月 23 日採用決定 